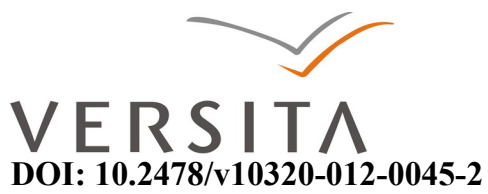

\title{
METAPHORICAL MIRRORS AND SUBVERTING SELVES IN ADRIENNE KENNEDY'S ONE-ACT PLAYS
}

\author{
GABRIELLA TÓTH \\ University of Szeged, \\ 6722, Egyetem u. 2, Szeged, Hungary \\ gabriella.toth@ieas-szeged.hu
}

\begin{abstract}
Beginning her career in the 1960s, Adrienne Kennedy was one of the most influential writers of the period. Her plays subverted both Western and African American theatre. Although like her contemporaries she reacted to the political events of the period, in contrast with them she presented racial issues in a non-realistic mode. Her plays exemplify the re-theatricalisation of the African American stage.
\end{abstract}

Keywords: African American drama, Feminist theatrical aesthetics

\section{Introduction}

Adrienne Kennedy began her career in the 1960s. At the time of the flourishing of the Civil Rights Movement, her plays subverted both African American and Western European theatrical traditions. I will be examining the links her plays have with Western playwriting. Concurrently, I will be highlighting the elements in her oeuvre that subvert this connection. Kennedy's plays are significant in African American drama. She entered the literary arena in a highly politicised era with highly "poeticised" dramas. This paper focuses on her early one-act plays, in particular Funnyhouse of a Negro (1962), The Owl Answers (1966) and A Movie Star Has to Star in Black and White (1976). The paper launches an enquiry into how the stage - as a heterotopic space - is able to construct new identities.

Adrienne Kennedy's early one-act plays delineate the - by definition fragmentary nature of a postmodern self. In A Movie Star Has to Star in Black and White, Clara, a young, Black, intellectual woman, asks, "Each day I wonder with what or with 
whom can I co-exist in a true union?" (Kennedy 2001:63) Her words do not apply only to this play and character, but basically to almost all the dramatic figures in Kennedy's plays. These characters are all tormented by their troubled psyches, resulting from the personal ontological crisis they face in a white, patriarchal world in which being African American, a woman and an intellectual are all reasons for being marginalised.

Kennedy's critics, such as Georgie Boucher (2006:84), Rosemary K. Curb (1980:180) and Claudia Barnett (199:374), argue that the dramatic figures in her works are characterised by split personality disorder. They tend to represent the 'mad woman in the closet'. According to Georgie Boucher, 'Kennedy's plays have remained controversial because of their failure to comply with the nationalistic orientation of the Black Arts Movement of 1960s America." (Boucher 2006:84-103)

Not only political but also economic and artistic reasons have prevented Black women playwrights such as Adrienne Kennedy from becoming part of mainstream theatrical trends. African American female dramatists, as Dana A. Williams argues, are "seldom given the degree of attention that is given to male playwrights." (1989:xvii) The reason "many published female playwrights go unnoticed" (1989:xvii) is that anthologies which collect only female playwrights "have limited space" and they are also few in number." (1989:xvii) Moreover, they remain "unread and unproduced" for various other reasons that range from "inherent shortcomings to the playwright's failure to promote a work extensively to discrimination by a male-dominated theatre world." (Williams 1989:xvii)

Being on the 'margin', however, is not seen exclusively as a disadvantage. Postcolonial feminist critics often see a form of resistance and a plethora of discourses challenging mainstream, white, patriarchal culture in this marginalised position. Sydné Mahone (Mahone quoted in Williams 1989:xvii), for instance, notes that African American women dramatists are excluded from mainstream American theatrical tradition since their plays "simply do not reflect the images and interest of the financially dominant culture, the white patriarchy." (1989:xvii) These playwrights present an alternative viewpoint to mainstream (Western) theatre. Thus they are celebrated more by forums that serve alternative and liberal art. Consequently, African American woman playwrights are marginalised in both American and patriarchal African American theatre. 
On the other hand, bell hooks points out in From Margin to Centre that "the margin need not be defined as a place that holds markings of less value. Rather for African Americans, it is a 'site of resistance' to racial and gender oppression, silence, despair and invisibility." (hooks quoted in Mahone 1994:xiii)

\section{The subverting theatre}

In the following section I focus on Funnyhouse of a Negro. Sarah is the protagonist of the play. This chamber play is an exciting montage of hallucinations, projected by the central character. The structure of the play not only signifies the protagonist's mental turmoil but also reflects the previously discussed challenging position of Black feminist drama, thus contributing to the creation of an autonomous Black female identity. Defining Kennedy's play as a Black feminist drama, we have to note that such definitions are never entirely adequate to label a piece of work. Nonetheless, the play that I am now discussing shows several characteristic features of both feminist and Black drama. According to Patricia Schrooder, in our approach to defining feminist drama as such, we have to focus on dramatic forms that "reflect women's experience." (Schrooder 1996:71) As she puts it, “a feminist play resists the oppression of traditional dramatic practice in theme and form, as well as in characterization." (Schrooder 1996:71) The form of Kennedy's plays is the key issue in this approach. Her plays resist the traditional, "hierarchical structure" (1996:71) of Western, male-dominated theatre. Such theatre forms are "male." (Reinhardt quoted in Schrooder 1996:71) As Nancy S. Reinhardt claimed:

The structure of traditional western drama 'imitation of an action' is linear, leading through conflict and tension to a major climax and resolution [...] One could even say that this aggressive build up, sudden big climax and cathartic resolution suggest specifically the male sexual response. (Reinhardt qtd. in Schrooder 1996:71)

Kennedy's plays, such as Funnyhouse, The Owl Answers, A Movie Star Has to Star in Black and White, are kaleidoscope-like. Not only do they lack a linear plot structure, they also question the images that African Americans could gain from nationalistic representations of Black culture. The scenes follow each other as in a 
mosaic. Kennedy's dramas usually do not contain coherent dialogues, but rather monologues, monotonously performed by the characters, who imitate a ritualistic chant with the trope of repetition. Her protagonist is a young Black intellectual girl, named Sarah. She is a student of English, living in a small chamber-like room on the top floor of a brownstone building in New York City's Westside. Struggling for a cohesive identity, she projects four iconic selves: Queen Victoria, the Duchess of Hapsburg, Jesus and Patrice Lumumba. Melanie Klein suggests that the play takes place in Sarah's mind (Klein quoted in Barnett 1997:123); Sarah projecting her inner turmoil. This would suggest, however, that the play has a central character. Negro-Sarah and her selves, however, are of equal importance.

We learn her family story from her first monologue and from the other characters, who are also her selves. She had a white mother; "she was the lightest one", who had straight hair like any white woman. Her father, on the other hand, was a black man, "the darkest one", who raped her mother. This mixed-race character lives in a society that excludes her from valuable human relationships, for she belongs neither to white nor to Black culture. Understandably a harmonious family and/or love relationship is her only wish:

I clung loyally to the lie of relationships, again and again seeking to establish a connection between my characters. Jesus is Victoria's son. Mother loved my father before her hair fell out. A loving relationship exists between myself and Queen Victoria, a love between myself and Jesus but they are lies. (Kennedy 2001:15)

\section{Me, myselves and I: the mirror as heterotopia}

Sarah wants to identify with her white friends: her Jewish boyfriend (who does not love her), and her white mother, as well as with white culture. She completely rejects her African heritage via her father's bloodline. Through her Queen Victoria self, she identifies with whiteness:

Victoria always wants me to tell her of whiteness. She wants me to tell her of a royal world where everything and everyone is white and there are no unfortunate black ones. For as we of royal blood know, black is evil and has been from the beginning. Even before my mother's hair 
started to fall out. Before she was raped by a wild black beast. Black was evil. (Kennedy 2001:14)

Her desire for whiteness is not only expressed by the obsessive identification with the historical figures of the Queen and the Duchess, but is also materialised in that she herself wants to be an "even more pallid Negro [... [ pallid like Negros on the covers of American Negro magazines; soulless, educated and irreligious." (2001:14) Her room is full of old books and artefacts: photos of English castles and monarchs, an oriental carpet and a large white statue of Queen Victoria that dominates the room. Besides these objects, mirrors appear on stage, both as part of the scenery (a mirror at a dressing table) and as props (e.g., a hand mirror). These mirrors, which appear both as actual objects and as connotation (via the title funnyhouse), are of major importance in the identity creation of Kennedy's play.

Using poetic language and montage stage settings, the play is surrealistic, dreamlike, as described in feminist aesthetics. In an interview, Kennedy said of her writings: "I see my writing as a growth of images. I think all my plays come out of dreams..." (Kennedy quoted in Patsalidis 1995:301) Her rather nightmarish settings are as Savas Patsalidis notes - the "stage version of the conceptual problem of Otherness and heterotopias." (Patsalidis 1995:301-2) Kennedy applies heterotopias in a Foucauldian sense (like the mirrors in Funnyhouse and other media, such as the movie screen (in $A$ Movie Star)). According to Foucault, heterotopias are places which are capable of "juxtaposing in a single real place several places; sights that in themselves are incompatible." (Foucault quoted in Patsalidis 1995:301) The mirror of Kennedy's funnyhouse pluralises the heterotopic nature of her play and thus strengthens the aspect of theatricalisation. The heterotopia in this case is the stage or theatre itself, which is a real space that brings together incompatible sights. In this way the mirror of the funnyhouse and the mirroring function of the theatre are copied onto each other, forming one unit. The two images construct a new metaphor that is the theatre itself.

Theatricality in the mode of character representation is the other key issue in Kennedy's play. Sarah creates four selves which all work as alternative subject positions for her. She is able to switch among these selves, resulting in a continuous acting out of roles. She imagines living together with these characters: 
The rooms are my rooms; a Hapsburg chamber [...]a chamber in a Victorian castle, the hotel where I killed my father, the jungle. These are the places myselves exist in [...] I find there are no places only my funnyhouse. (Kennedy 2001:15)

At other times, Sarah believes that she is actually the characters herself and that instead of living with her boyfriend Raymond (the Jewish poet) she is living with the husband either of Queen Victoria or of the Duchess of Hapsburg: "Part of the time I live with Raymond, part of the time with God, Maxmilian and Albert Saxe Coburg." (Kennedy 2001:13)

By the same token, as she is the creator of these roles/selves, she functions as metaphorical author/director. By this, Kennedy subverts the world-as-theatre analogy, in which, typically, "the white man" (and in some cases the white woman) has "traditionally been a despotic director or an omniscient dramatist." (Patsalidis 1995:301-2) Her authority, however, collapses when she loses her control over her multiple selves, which ultimately leads to her death.

The background story of Sarah's family relations is one of the key elements in subverting the traditional topic of black theatre, which is either "blacks confront white world, like in revolutionary theatre" (Fabre 1983:111)' or "blacks confronting one another, which depicts whites only parenthetically." (Fabre 1983:111) In this play the conflict is not external, i.e. social-based, but internal, that is psyche-based. The funnyhouse in the title is significant not only because it is the "metaphor of America" (Fabre 1983:111) but also because it represents Sarah's identity crises, "Who am I?" The mirror, in Jaques Lacan's theory of subject formation, symbolises the mirror stage, which is necessary in order to develop a well-balanced, healthy ego. The mirrors in the funnyhouse help the protagonist to glimpse her identity (even if this is only a mirror image). Moreover, they also serve as the metaphor of the function of traditional classicrealistic theatre: that is, to hold a mirror up to society. Thus, Funnyhouse of a Negro does not eliminate the white audience but on the contrary universalises Sarah's mental struggle to find her identity and make peace with her ancestry with a gesture of theatricality. 


\section{Surrealistic characterisation: the owl and the dog}

The story of Kennedy's characters in general could be represented in a realistic mode, as was done by some of her predecessors, for example in Raisin in the Sun by Lorraine Hansberry. In such a representation, there had always been a correlation between representation and referent. In other words, this kind of theatre creates the illusion of the harmony between character and actor, role and the social sphere, as well as between actions, meaning that actions follow each other in a teleological order.

This mode of representation - in Ihab Hassan's understanding - follows the structuration of postmodern drama, in which "Things and subjects are simultaneously out of their proper time and topos." (Patsalidis 1995:305) The play represents pluralism, e.g. in the mode of staging Sarah's story. It applies both tools of an analytic play (we learn about her family from the characters) but the audience is dropped into the surrealistic imagery of a split mind. Randomness and discontinuity are the chief ingredients of plot organisation, because the order of the scenes could be changed or exchanged. Instead of the integration of the subject into the proper social order, disintegration ends the play, with Sarah committing suicide. Representational reality is eliminated from Kennedy's plays since it cannot, by definition, characterise African American culture. As Kennedy notes: "ambivalence, deterritorialization, heterogeneity, plurality, eclecticism, discontinuity, parody, paradox reign supreme" instead.

In this section, I highlight the common denominators of character representation in The Funnyhouse, The Owl and The Lesson in Dead Language. The notion of character is the most problematic in this mode of representation, since it is deconstructed throughout these plays. So far we have seen that Sarah, by projecting her selves, is acting out four roles. Her role playing, however, is imperfect. Although she wants to be a queen or a duchess she can never become one, and the ultimate result of her fantasy of being someone else is her death. Turning this problem upside down and inside out, the projected selves of Sarah also act a role. They all appear as Sarah's created egos, and thus we can interpret them - as if in a reversed minstrel show - as playing Sarah herself. The characters constantly estrange themselves from the roles in which they are cast, by announcing that they are the people who they are playing, thus revealing the very 
constructedness of theatricality. Negro Sarah acts two female and two male roles. At the same time, from the projected selves' point of view, these characters act out Sarah. Either way, the harmony between actor/role/character is questioned. Thus the play theatricalises the role-playing nature of the search for an identity.

I used the term reversed minstrel to refer to a phenomenon that can be defined as play passing in subject theory. Kennedy's alter egos, Sarah in Funnyhouse or Clara Passmore in The Owl Answers and Clara in A Movie Star, all apply some form of "passing" in their lives. The reason for this is the same - their gender and/or race is not good enough in their surroundings. "Passing" in African American lingo refers to someone's desire or ability to successfully conceal their blackness to the extent that they "pass" for white. The outcomes of the various characters' attempts at passing, however, differ in nature.

Enikő Bollobás differentiates two types of passing in subject formation theory. Passing, as she defines it, is "a way of escaping metaphysical or logocentric binaries, whether between genders, races, sexualities or classes". (Bollobás 2010:14) It is, in other words, a form of "social performance." (2010:14) Passing can be either full or play passing. In the first case, the "aim is to deceive, to be altogether the same", which is always a performance. (Bollobás, 2010:14) In the latter case, however, we can consider it an "interrogation and subversion of the binary system and as such [is] always a performative creation of new ontologies.” (Bollobás 2010:14)

Full passing (performance) and play passing (performativity) according to this theory represent the two procedures through which the subject comes into being. In the first case, the subject is created to be an inactive entity, obediently acting out the socially prescribed roles that are assigned to his or her subject position. In the latter case, however, the subject constructs itself to become an "active agent" (Bollobás 21). Kennedy's heroines progress on this scale of performance-performativity. We usually see them in a catachrestic state of mind, in other words, in a personal ontological and epistemological crisis. This mental existence means that the characters act performance that goes beyond the normativised gender, race or class ascribed to a given person. In such writings, women construct themselves into new subjects" (Bollobás 14). 
In both The Owl Answers and a Lesson in Dead Language, the character-role harmony is deconstructed in the extremities. In The Owl, the protagonist is "She who is CLARA PASSMORE who is the VIRGIN MARY who is the BASTARD who is the OWL." (Kennedy 2001:29) While in The Owl the characters keep their human nature most of the time, in Lesson in Dead Language, the pupils' costumes look identical, as if deprived of any personal features. The central character (not protagonist though) is played by an actor wearing the mask of a white dog, who is completely dehumanised.

Clara Passmore in The Owl Answer is in her thirties. She is a school teacher from Savannah, Georgia, who goes to England. Her story is even more blurred than Sarah's. While in Sarah's case the character's parentage was clear, in the case of Clara we cannot be entirely sure who her ancestors are. Her DEAD WHITE FATHER for whose burial she arrives at St. Paul's Chapel in London, is either THE RICHEST WHITE MAN IN THE TOWN or REVEREND PASSMORE (or the GODDAMNED FATHER). Likewise, her mother has plural identities. She is the "BASTARD'S BLACK MOTHER who is the REVEREND'S WIFE who IS ANNE BOLEIN”. (Kennedy 2001:29) In both cases, the heroine identifies with white culture, which is represented by great historical figures; in the latter case by SHAKESPEARE, CHAUCER and WILLIAM THE CONQUEROR. These figures play the guards at St. Paul's Chapel and slam the gate shut in Clara's face when she tries to enter to see her dead father. Her right to take part in her white father's burial is denied from her

THEY. Bastard. [...]

SHE. You must let me go down to the Chapel to see him. He is my father. [...]

THEY. Keep her locked there, guard. ...

SHE. We came this morning. We were visiting the place of our ancestors, my father and I. We had a lovely morning, we rose in darkness, took a taxi past Hyde Park through the Marble Arch to Buckingham Palace, we had our morning tea at Lyons than came out to the tower. We were wandering about the gardens, my father leaning on my arm, speaking of you William the Conqueror. My father loved you William ...

THEY. (Interrupting) If you are his ancestor, why are you a Negro? (Kennedy 2001:30) 
Clara Passmore and the rest of the characters change and exchange their roles as if it were costumes and masks and fake hair.In the stage directions Kennedy writes:

The characters change back and forth into and out of themselves, leaving some garment from their previous selves upon them always to remind us of the nature of She who is Clara Passmore who is the Virgin Mary who is the Bastard who is the Owl's world. (Kennedy 2001:29)

This passage again exemplifies the issue of passing. The protagonist has a talking name that refers to the act of full passing, since she is longing to identify with white culture; she attempts to pass more - more than the "unfortunate blacks" as Sarah says. However, her passing is imperfect, indeed impossible. But explicitly revealing the impossibility of such an act by presenting and deconstructing it at the same time results in the act of new self construction as play passing. By presenting the drama of passing (either full or play), Kennedy's plays unmask the social constructedness of gender, race and class with one hand and unveil the role playing nature of one's identity with the other.

\section{What she saw in the movies}

The idea of identifying with white culture through various media, and simultaneously the impossibility of it, are reccurring themes in the Kennedy corpus. The fourth drama discussed here, A Movie Star has to Star in Black and White, is the most conspicuous one in this regard.

Thirty-three-year-old Clara is the protagonist of this very complex play. She is represented within a society that forces her into a double bind, affecting her entire life. She is expected to fulfil the role of an angelic woman in her domestic realm, as well as in her public domain. She experiences normativising processes of her immediate as well as of her extended environment through both the heritage of her family and the media. In a catachrestic state of mind, she is alienated from herself and her environment; she fails to achieve a cohesive identity. In this alienation, she gives up her efforts to maintain harmonious relationships. Instead, she reconstructs herself - her subject position through the act of writing. Her femininity is defined in relation to her writing: menstrual 
blood becomes her 'ecriture feminine', and her labour of creative output is symbolised by her pregnancy.

There are two basic attitudes that African American women have regarding their position, which is mainly ascribed to them through an unspoken ideology that comes through the media, ranging from Hollywood films of the era, via magazines (with photos of "pallid Negros"), to European cultural heritage, conveyed via school books ("old volumes") and photos of castles and great monarchs. The first attitude is the one that is embraced by Clara Passmore, Sarah, and the girls in a Lesson in Dead Language. They all turn to a special heterotopic place, a metaphorical mirror, to find the object of their identification. In their case, the movies and other media alike function like a "mirror", like the Lacanian mirrors in Funnyhouse of a Negro (see section 2).

Kennedy - like her alter ego, Clara - in her childhood also experienced a fascination with Hollywood movies and the persona of Bette Davis in particular. In her biographical book People, Who Led to My Plays she writes:

\footnotetext{
She was plain. She was troubled. She was controlled by her mother and then one day she took a trip on an ocean liner and total fulfillment came to her because of this trip on the ocean. She became beautiful and loved. One day I'm going to take a trip on an ocean liner, I thought, and all of my dark thoughts and feelings, all my feelings that I don't belong anywhere, will go away (Kennedy 91).
}

Applying the theory of the mirror stage in Lacan's psycho-analysis, Deborah R. Geis argues that Kennedy/Clara turns to the symbolic realm of the movies to find a mirror, but instead sees the reminder of her Otherness (1992:173). Clara, the heroine of the play, at a certain point in the drama asks: "Each day I wonder with what or with whom can I co-exist in a true union?" (Kennedy 2001:65). Critics such as Geis argue that this means that Clara is an alienated subject, who "speaks to re-inscribe herself as an ego ideal, but who can only do so at the imperfect level of identity with an object" (Geis 1992:174). The "true union" - as Geis puts it - "is as unlikely as the possibility that she could become her Bette Davis persona" (992:175). Clara's position resembles that of Sarah in Funnyhouse or Miss Passmore in The Owl, whose complete identification with whiteness is just as unlikely. 
A critical position is attributed to Clara. She is a playwright, writing her own drama, by which she takes the first step towards gaining her own voice. Creativity and writing, as such, usually characterise male characters/authors. In their essay Madwoman in the Attic, Sandra M. Gilbert and Susan Gubar write that the author "is a progenitor, a procreator, an aesthetic patriarch whose pen is an instrument of generative power like his penis" (Gilbert and Gubar 1979:6). Although it is debatable whether or not female writing can be defined in terms of biological essentialism, Gilbert and Gubar propose the question, regarding creative metaphors: "If the pen is a metaphorical penis, from what organ can females generate texts?" (Gilbert and Gubar 1979:7) The logical answer to this question seems to be the womb. The text, then, the 'ecriture feminine', comes forth from the body as milk and blood.

In Lesson in Dead Language, the Pupils all wear white organdie dresses, white socks and black shoes. (Kennedy 2001:43) Visible on the backs of their uniform dresses (as they stand with their backs to the audience) are great circles of blood. (2001:44) The pupils in the play are faced with the terrifying experience of menstrual blood, both as a physical sign of the end of their childhood and the beginning of their womanhood, and as the metaphor of their creative abilities.

PUPIL. I bleed Teacher, I bleed. It started when white dog died. It was a charming little white dog. He ran beside me in the sun when I played a game with lemons on the green grass. And it started when I became a woman. My mother says it is because I am a woman that I bleed. (Kennedy 2001:44)

If Lesson in Dead Language allegorises the beginning of womanhood, the loss of a girl's innocence through experience and the beginning of feminine creative power, $A$ Movie Star presents female creativity at its peak. The heroine is pregnant, bleeds and writes at the same time. In this way the menstrual blood turns into the metaphorical ink.

This play presents a multi-layered theatricality by presenting Clara's life (and drama) through two media: film and theatre. With this she occupies a critical position in opposition to Hollywood representations. Each scene of Kennedy's play starts with a film set, in which the leading roles are played by actors who look exactly like Bette Davis, Jean Peters, Marlon Brando, Montgomery Clift and Shelley Winters. The "real 
characters", who are people from Clara's life (her father, mother, husband and brother) appear only as "Supporting Roles" (Kennedy 2001:63). Clara actually plays only "a bit role" (2001:63). The movies Now, Voyager (1942), Viva Zapata (1952), and A Place in the Sun (1951) appear in the play. By the fact that white actors act out the lives of Clara and her family, Kennedy critiques Hollywood's American Dream fantasy and its exclusion of African American actors. Laura Mulvey argues that the type of visual representation (narrative cinema) which these films represent "manipulated our sense of visual pleasure through the coercive act of $\operatorname{cod}[i n g]$ the erotic into the language of the dominant patriarchal structure" (Mulvey in Geis 173). The powerful impact of the cinema does not influence female audiences alone. Female and male African American filmgoers alike face similar difficulties in finding an object of identification when they watch movies with exclusively white actors.

At this point we can conclude that the beauty and body images in Clara's life that come from the idealised movie images and her emotional attitude within her family are closely interwoven and are the cause of her catachrestic - or, as she puts it, "catatonic" (Kennedy 2001) - state of mind. These types of Hollywood movies offered only a limited set of positions with which women film-goers could identify, such as the figure of the well disciplined, obedient girl (Bette Davis in Now, Voyager) or the femme fatale type (Elizabeth Taylor in A Place in the Sun). Nonetheless, these women characters, according to Enőkő Bollobás’ criterion of performance/performativity, can be all categorised as women acting out performances at the beginning of the film plot and become performative by the end of their actual or mental journey. One example of this is the role of the 'angelic woman' that is expected of Clara in Kennedy's play. Bette Davis (for Clara) says: "I've always felt sad that I couldn't have been an angel of mercy to my father and mother and saved them from their torment" (Kennedy 2001:64). The women in the play - and this is also common in popular representations - blame themselves for their unsuccessful family life. Note that not only Clara, but her mother as well, tries to fulfil the role of a perfect wife and mother, i.e., the 'angelic woman'. Despite all of her efforts, however, Clara's mother fails. In the second scene, she asks of Clara in the utmost despair: "What did I do? [...] I don't know what I did to make my children so unhappy" (Kennedy 71). 
Susan J. Douglas argues that the miserable life of a poor black family would evoke nothing but "repulsion" (Douglas 1995:8). In Kennedy's drama, these miserable scenes are acted out by white actors. In this way, the ideology of the perfect world conveyed by Hollywood movies is subverted, with the result that identification will be equally difficult with these lives on both sides. The play would, however, lose much of its subverting nature if it were not been for the character of Clara. The playing of black lives by white actors would simply reinforce the position of African American people in society, since this playing is only the performing of already existing social roles.

\section{Conclusion}

Adrienne Kennedy's plays subvert the traditional Western European theatre by applying postmodern dramatic features. Her works are comprised of non-linear, nonteleological scenes in order to best represent the characters' identity crises. Negro-Sarah in Funnyhouse or Clara Passmore in The Owl Answers and their multiple selves do not have traditional dialogues. The plays consist of parallel monologues. Instead of a hierarchical relationship, they are related to each other paradigmatically; none of them is more important than any other. The connection of the characters to one another on the one hand, and the non-teleological plot on the other, result in a feminist aesthetics.

The characters' identity crises in the plays often, as we have seen, result from the various forms of media (films, magazines, photos, cultural artefacts) which communicate the ideal of whiteness, family life, and ascribed subject positions (mother, daughter, angel or fallen woman) to these female characters. They turn to these constructed images as if to a mirror, yet their Otherness becomes only the more striking. Their solution is either full or play passing. The first, by its impossibility, and the latter, through its subversive nature, are both capable of showing the constructed nature of race, gender and class categories.

Clara's ambition to become a writer allegories the performative nature of the play. Clara's inability to take either the angelic or the demonic female role makes her character subversive. Her pregnancy and menstrual blood (just like the blood in Lesson in Dead Language) are both the metaphors of female artistic creativity, which might be a way out 
of her trapped situation. Creativity, as such, helps the characters to gain a voice; they thus become - using Enikő Bollobás' term - active agents, instead of passive submissive ones.

\section{References}

Barnett, C. 1997. ‘A Prison of Object Relations: Adrienne Kennedy’s Funnyhouse of a Negro' in Modern Drama 40. 3 Fall,

Bollobás, E. 2010. 'They Aren't, Until I Call Them': Performing the Subject in American literature. Frankfurt. Main: Peter Lang.

Boucher, G. 2006. 'Fractured Identity and Agency and the Plays of Adrienne Kennedy' in Feminist Review - Postcolonial Theatres. [Online]. Available: http://www.jstor.org/stable/30232741 [2011, January 6]

Douglas, S. J. 1995. Where the Girls Are: Growing Up Female with the Mass Media. New York: Three Rivers Press

Curb, R. K. 1980. 'Fragmented Selves in Adrienne Kennedy's Funnyhouse of a Negro and The Owl Answers' in Theatre Journal [Online]. Available: http://www.jstor.org/stable/3207111 [2011, January 6]

Geis, D. R. 1992. ‘A Spectator Watching My Life: Adrienne Kennedy’s A Movie Star Has to Star in Black and White' in P. K. Bryant-Jackson and L. More Overbeck (eds). Intersecting Boundaries: The Theatre of Adrienne Kennedy Minneapolis. University of Minnesota Press.

Gilbert, S. M.; Gubar, S. 1979. The Madwoman in the Attic: The Woman Writer and the Nineteenth-Century Literary Imagination. New Haven, Connecticut. Yale University Press.

Kennedy A. 1987. People Who Led to My Plays. New York: Knopf Inc.

Kennedy A. 2001. Funnyhouse of a Negro in W. Sollors (ed.). The Adrienne Kennedy

Reader. Minneapolis. University of Minnesota Press,

---. 2001. A Movie Star Has to Star in Black and White in W. Sollors (ed.). The

Adrienne Kennedy Reader. Minneapolis. University of Minnesota Press,

---. 2001. The Owl Answers in W. Sollors (ed.). The Adrienne Kennedy Reader.

Minneapolis. University of Minnesota Press,

---. 2001. Lesson in Dead Language in W. Sollors (ed.). The Adrienne Kennedy

Reader. Minneapolis. University of Minnesota Press.

Bell Hooks. 1994. 'Introduction' in S. Mahone (ed). Moon Marked and Touched by Sun: Plays by African-American Women. New York. Theatre Communications Group.

Patsalidis, S. 1995. 'Adrienne Kennedy's heterotopias and the (Im)possibilities of the (Black) Female Self ' in M. Maufort (ed.). Staging Difference Cultural Pluralism in American Theatre and Drama. New York: Peter Lang Publishing 
Inc.

Schrooder, P. R. 1995. 'American Drama, Feminist Discourse, and Dramatic Form: A Defense of Critical Pluralism' in K. Laughlin and C. Schuler (eds.). Theatre and Feminist Aesthetics. London: Associate University Press.

Williams, A. D. 1989. 'Introduction' in D. A. Williams (ed.). Contemporary African American Female Playwrights: An Annotated Bibliography. Westport, Connecticut: Greenwood Press. 